\title{
Evaluate the outcome of pneumonectomy for stage III a-N2 NSCLC
}

\author{
Sungjoon Park, Hyo-Jun Jang, Eunjue Yi, Sukki Cho, Sanghoon Jheon, Kwhanmien Kim* \\ From World Society of Cardiothoracic Surgeons 25th Anniversary Congress, Edinburgh \\ Edinburgh, UK. 19-22 September 2015
}

\section{Background/Introduction}

The effect of surgery in patients with III a-N2 non-small cell lung cancer is not certain.

\section{Aims/Objectives}

We intend to evaluate the outcome of pneumonectomy in III a-N2 non-small cell lung cancer.

\section{Method}

We retrospectively reviewed the cases of patients with III a-N2 non-small cell lung cancer, who underwent pneumonectomy from April 2003 to January 2014 at a single institution.

\section{Results}

During the study, 184 patients underwent surgical resection of stage III a-N2 non-small cell lung cancer. Among them, 35 patients had pneumonectomy, 29 patients $(83 \%)$ were male, and $6(17 \%)$ were female. The median age was 57 years ( 43 yrs- 77 yrs) old, and the median follow up duration was 77 month. 27 patients (77\%) had induction chemotherapy before operation. Right pneumonectomy was performed in 13 patients (37\%), and Left pneumonectomy was done in 22 patients (63\%). The 5 -year survival was $58 \%$ in pneumonectomy, $28 \%$ in the right pneumonectomy and $76 \%$ in the left pneumonectomy, respectively. Left pneumonectomy $(\mathrm{p}=0.021)$ and complete resectability $(\mathrm{p}=0.017)$ were positive prognostic factor, but the induction chemotherapy before operation was negative prognostic factor. $(\mathrm{p}=0.040)$

\section{Discussion/Conclusion}

The side of operation and complete resectability are positive prognostic factor, but the induction chemotherapy is

Department of Thoracic and Cardiovascular Surgery, Seoul National University Bundang Hospital, Seoul National University College of Medicine, 166 Gumi-ro, Bundang-gu, Seongnam-si, Gyeonggi-do 463-707, Seoul, Korea negative prognostic factor for pneumonectomy in III aN2 NSCLC patients.

Published: 16 December 2015

doi:10.1186/1749-8090-10-S1-A206

Cite this article as: Park et al:: Evaluate the outcome of pneumonectomy for stage III a-N2 NSCLC. Journal of Cardiothoracic Surgery 2015 10(Suppl 1):A206.
Submit your next manuscript to BioMed Central and take full advantage of:

- Convenient online submission

- Thorough peer review

- No space constraints or color figure charges

- Immediate publication on acceptance

- Inclusion in PubMed, CAS, Scopus and Google Scholar

- Research which is freely available for redistribution
() Biomed Central 